impact on the reader, synthesizing the modern achievements of mass culture. Various verbal and artistic codes are intermingled, forming a kind of semantic discourse.

The characteristic features of Roald Dahl's parody are the genre evolution of poetic fairy tales, the violation of taboo topics. One can trace the intensity of intrigue, the mystery of the content in the compositional structure of his rhymes. All Dahl's verses differ in modern details and the language of the main characters. Turning to fairy-tale motifs, R. Dahl transformed them, introduced modern things, household trifles.

The comicality of R. Dahl's texts is realized with the help of linguistic means of creation situational humor: epithets, metaphors, similes, hyperbole. The work acquires an ironic color due to the use of slang and vulgarisms.

The perception of messages by both the characters within the text and the reader is determined by the degree of awareness of each of them. R. Dahl's individual style is characterized by the widespread use of print expressiveness: various fonts, italics, brackets and capitalization. Roald Dahl's language is characterized by simplicity and conciseness, which is achieved through the selection of words that ensure the accuracy of the opinion.

Key words: comic, parody, ironic flavor, fairy tale plot, folklore basis.

DOI: https://doi.org/10.32782/2410-0927-2020-12-12

УДК $811.11 ’ 42-11$

Оксана Гураль

\title{
КРЕАТИВНА ЕКСПРЕСИВНІСТЬ АНГЛОМОВНОГО ПОСТМОДЕРНІСТСЬКОГО РОМАНУ У СВІТЛІ ТЕОРІЇ КОНЦЕПТУАЛЬНОГО БЛЕНДІНГУ
}

Стаття присвячена розкриттю специфіки застосування теорії концептуального блендингу та теорії концептуальної метафори для аналізу глибинної семантики постмодерністського англомовного наративу. Оскільки когнітивний підхід до аналізу тексту розкриває значно більші можливості для тлумачення текстових тактик та індивідуально-авторських прийомів, він $є$ надзвичайно актуальним на сьогодні.

У статті подано зіставлення теорії концептуальної метафори та концептуального блендингу за декількома параметрами - порівняно спосіб застосування, одиниці аналізу, можливості, що з'являються при аналізі художнього тексту, а також їхній евристичний потенціал. В той час як перша концентрує свої зусилля на пошуку узагальнень у широкому спектрі метафоричних виразів, друга - фокусується на природі і особливостях специфічних прикладів, сприяючи виокремленню загальних принципів такої побудови. Незважаючи на те, що текст англомовного постмодерністського наративу значною мірою структурують конвенційні концептуальні метафори, вони зазнають різноманітних деформацій у процесі реалізації авторського творчого задуму, а саме - розширення, компресії, зміщення, використання раніше невикористаної частини концептуальної метафори.

У статті запропоновано аналіз новаторських концептів за допомогою теорії концептуального блендингу. Зокрема, проаналізовано появу додаткової семантики у емергентному просторі блендів LIFE IS ANTI-COMEDY, DOCTOR IS FIEND; розкрито особливості концептуальної моделі гіпотетичного судження алюзивного характеру: "But say Thumberlina had married the mole?”, висвітлено приріст значення у випадку складеного іменника ВОМВ ВАВY. Таким чином розкриваємо додаткові можливості теорії концептуального блендингу для моделювання глибинної семантики індивідуально-авторських висловів при зіставленні із теорією концептуальної метафори.

Ключові слова: концептуальний бленд, ментальний простір, концепт, концептуальна метафора, гіпотетичне судження.

Вступ. У сучасній авангардній художній літературі, до якої відносимо і романи М. Аміса, спостерігаємо прагнення до деконвенціоналізації стилістичних прийомів та наративних тактик, що у свою чергу стимулює процеси словотворення, збагачує мову додатковими смислами, відкриває нове бачення усталених речей. Хоча питання про новаторство більшості прийомів постмодерністської літератури залишається дискусійним: безліч з них запозичені з надбань попередників, прагнення до епатажу та деавтоматизації сприйняття штовхає автора на сміливе експериментаторство, застосування новаторських текстових прийомів та оповідних тактик, аналіз глибинної семантики яких потребує відповідного інструментарію.

У контексті когнітивного підходу до моделювання процесів читацької реконструкції тексту художнього твору Л. Зуншайн, Е. Семіно, П. Стоквела актуальним залишається застосування теорії концептуального блендингу Ж. Фоконьє, М. Тернера для пояснення семантики інноваційних художніх концептів, що втілюють авторський ідіосинкретичний спосіб інтерпретації дійсності. Когнітивна інтерпретація концептів такого типу виходить за мережі

(C) Гураль О., 2020 
перенесення значення між двома доменами знання (cross-domain mapping), постульованого теорією концептуальної метафори.

Застосування методики теорії концептуального блендингу є продуктивним напрямом у розробках західних [15] та вітчизняних фахівців [12; 14; 17; 18]. Мовне експериментаторство постмодерністського тексту притягує науковий інтерес [9], про що свідчить поява таких термінів, як “ігрова стилістика" [12], “полістилістика" [7] стосовно цього типу наративу. Оскільки когнітивна лінгвістика на даний час існує лише як напрям, сукупність взаємодоповнювальних, конкуруючих теорій, які часто накладаються одна на одну і пояснюють те саме явище за допомогою різної термінології [10, с. 3], метою цісї статті є з'ясувати, які саме переваги для розкриття семантики новаторських індивідуально-авторських прийомів англійського письменника-постмодерніста М. Аміса відкриває теорія концептуального блендингу у порівнянні $з$ теорією концептуальної метафори. Відтак ставимо перед собою завдання: 1) виокремити випадки авторської словотворчості, концептуальний аналіз яких вимагає виходу за межі теорії концептуальної метафори; 2) проаналізувати випадки прирощення значення $з$ погляду теорії концептуального блендингу; 3) встановити спектр можливостей i переваг, які надає такий підхід.

Методи і методики дослідження. У статті використано інтерпретативний метод із застосуванням стилістичного аналізу тропів та фігур, а також метод концептуального аналізу (теорії концептуального блендингу Ж. Фоконьє, М. Тернера та концептуальної метафори Дж. Лакоффа). Порівняння потенціалу обох теорій для аналізу тексту художнього твору містить така таблиця:

\section{Теорія конщептуальної метафори}

Оскільки сама природа нашого мислення $\epsilon$ метафоричною, то людську концептуальну систему прийнято трактувати як мережу конвенційних концептуальних метафор, усталених способів інтерпретації власного бачення дійсності (projected reality), що передбачає розуміння абстрактних концептів через конкретні шляхом міждоменного перенесення (cross-domain mapping).

Задіяні два домени.

Домени є усталеними формами знання, структура яких великою мірою визначена імідж-схемою, рудиментарним концептом, що бере початок у фізичному долінгвальному досвіді взаємодії людини із навколишнім середовищем.

Домени - відносно стабільні структури знання.

Міждоменне перенесення відбувається в одному напрямку: домен-джерело надає свою структуру для домену-цілі.

\section{Теорія конщептуального блендингу}

Для пояснення процесу побудови значення в динаміці запропоновано інтеграційні мережі тимчасових ментальних просторів. Теорія концептуального блендингу намагається дати оцінку “креативним аспектам" побудови значення (новаторським метафорам, гіпотетичним судженням).

Задіяні чотири ментальні простори і більше.

Складні мережі пов'язують два (чи більше) вхідніх простори (input spaces) через простірджерело (generic space), що містить інформацію, спільну для обох входів. Четвертий простір бленд, містить нову емергентну структуру (emergent space). У ньому відбувається вибіркове поєднання елементів 3 обох вхідних просторів. У свою чергу цей простір генерує нову структуру, значення якої складників більше, ніж сума [11, c. 40-49].

Ментальні простори - тимчасові утворення, залучені у процес інформаційної обробки.

Топологічна структура одного домену проектується на інший - одномасштабна мережа (single-scope integration network). Водночас існують бленди, що мають характер подвійного фреймового перенесення - рівномасштабні (double-scope network); a також множинні багатомасштабні мережі (multiple-scope network). Ця теорія передбачає вибіркове перенесення інформації 3 двох вхідних просторів у простір- 


\begin{tabular}{|c|c|}
\hline & $\begin{array}{l}\text { бленд, окрім цього структура бленду } \\
\text { проектуватися назад на вхідні простори. }\end{array}$ \\
\hline $\begin{array}{l}\text { Мета: перенесення конвенційних патернів, } \\
\text { закріплених у концептуальній структурі. }\end{array}$ & $\begin{array}{l}\text { Мета: розкрити суть динаміки процесу побудови } \\
\text { значення. }\end{array}$ \\
\hline $\begin{array}{l}\text { Концентрує зусилля на пошуках узагальнень у } \\
\text { широкому спектрі метафоричних виразів / } \\
\text { висловів. }\end{array}$ & $\begin{array}{l}\text { Фокусується на природі і особливостях } \\
\text { специфічних прикладів, сприяючи виокремленню } \\
\text { загальних принципів такої побудови. У центрі } \\
\text { уваги тут локальний, динамічний процес } \\
\text { побудови значення }[10, \text { с. } 404,436] .\end{array}$ \\
\hline $\begin{array}{llr}\text { Більшість концептуальних } & \text { метафор } & \text { можна } \\
\text { iнтерпретувати у вигляді } & \text { блендів, } & \text { окрім } \\
\text { первинних метафор (primary metaphors). } & \end{array}$ & $\begin{array}{l}\text { Не всі концептуальні бленди є метафоричними, } \\
\text { деякі відображають гіпотетичні судження чи } \\
\text { складені іменники, утворені шляхом поєднання } \\
\text { вільних морфем. }\end{array}$ \\
\hline
\end{tabular}

Результати та дискусії. Оскільки тексти авангардного експериментального характеру написані тією ж повсякденною мовою, природа якої є метафоричною, більшість відслідкованих концептуальних метафор в них конвенційні. Структурування концепту за допомогою перенесення значення домен-джерело $\rightarrow$ домен-ціль дозволяє висвітлити один 3 аспектів концепту. Водночас, як стверджує Р. Цур, один із основоположників когнітивно-поетичного напряму, у художній творчості спрацьовує принцип поетичного насилля над когнітивними процесами: створення i сприйняття художнього твору передбачає поряд зі сталим використанням когнітивних процесів їх модифікацію, порушення, а іноді і деформацію, що викликане адаптацією цих процесів до цілей, для досягнення яких вони первісно не були пристосовані [16, с. 4-5]. Водночас представник іншої течії в когнітивній лінгвістиці Дж. Лакофф розрізняє три варіанти утворення творчої/неконвенційної метафори: 1) розширення, 2) використання раніше невикористаної частини загальноприйнятої метафори, 3) власне нова метафора, що раніше не використовувалася для структурування відповідної частини звичайної понятійної системи людини [13, с.90]. Відтак виокремлюємо такі типи модифікації конвенційних метафор у романах М. Аміса:

1) розширення: GOOD LOOKS IS POWER "But let us be clear about this: she had great powers great powers. All women whose faces and bodies more or less neatly fill the contemporary mould have some notion of these privileges and magics... there they are, in a China-sixed woodland of teak-hard worship." [1, c. 20];

2) компресія: мовленнєва одиниця може експлікувати метафору в стисненому вигляді. До прикладу, заголовок роману М. Aміса "Yellow Dog" [4] є фактично компресією концептуальної метафори YELLOW JOURNALIST IS A DOG. Підгрунтям цієї метафори $є$ подібність дій собаки, що шукає їжу, річ, та журналіста таблоїду, який займається „жовтою журналістикою" (yellow journalism), задіяного в процесі збору, створення та подачі сенсаційних, часто недостовірних новин;

3) змішення: LOVE IS A HUMAN BEING $\rightarrow$ LOVE IS A PATIENT: "The diagnosis was in on love, the diagnosis was coming in; and love was as weak as a kitten, and pitifully confused, and not nearly strong enough to be brave or even understand" [1, c. 297]; LIFE IS A PLAY $\rightarrow$ LIFE IS A HORROR FILM: "When you become old, you find yourself auditioning for the role of a lifetime; then, after interminable rehearsals, you are finally starring in a horror film - a talentless, irresponsible, and above all low-budget horror film, in which (as is the way with horror films) they're saving the worst for the last' [6, c. 3];

4) використання раніше невикористаної частини конвенційної метафори LIFE IS A JOURNEY: "Suicide isn't an option, is it. Not in this world. Once you're here, once you're on board, you can't get off. You can't get out" [2, c. 33]; "Keith was now well launched on the bullet train of his fifties? Where the minutes often dragged, but the years tumbled over one another and disappeared' [6, c. 115].

Дещо більші можливості для аналізу таких висловлень з'являються при застосуванні теорії концептуального блендингу - вона здатна пояснити приріст значення, що виходить за межі перенесення між двома доменами. Наприклад, життя персонажа роману “The Information" 
Річарда Тула, письменника-невдахи, за його власним визначенням, набуває ознак нового жанру: "His life, his whole life, was approaching its third-act climax. There would be two acts to follow. The fourth act (conventionally a quiet act). And then the fifth. What genre did his life belong to? That was the question. It wasn't pastoral. It wasn't epic. In fact, it was comedy. Or anti-comedy, which is a certain kind of comedy, a more modern kind of comedy" [3, c. 179].

У наступній схемі, що є моделлю концептуального бленду LIFE IS ANTI-COMEDY, обидва вхідні простори $(1,2)$ дають підстави для зівставлення, оскільки мають спільну топологію, яку в цій схемі ілюструє простір-джерело / generic space, а саме жанр, структурний елемент, кульмінація, кінець.

\section{Ілюстративна репрезентація концептуального бленду LIFE IS ANTI-COMEDY}

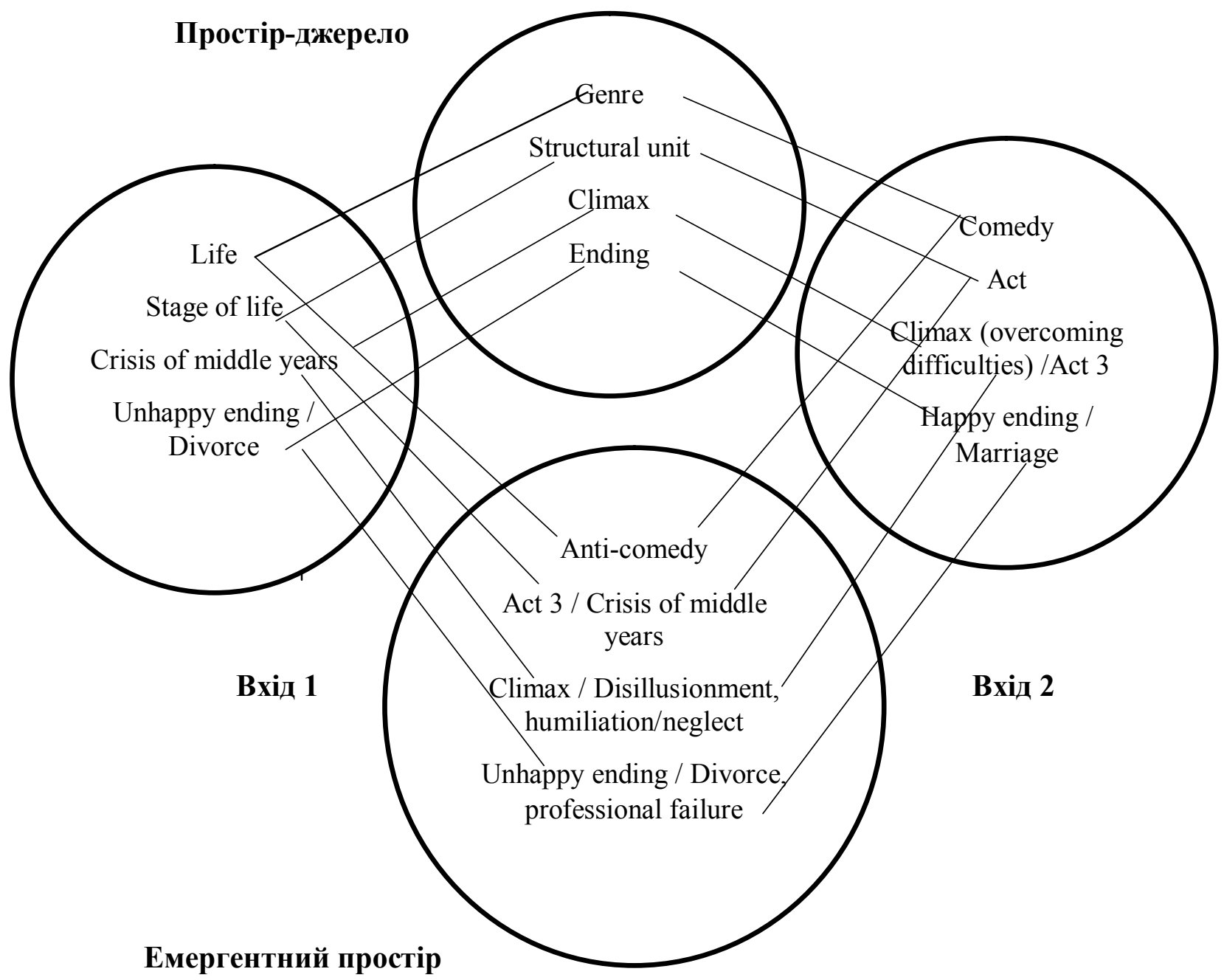

Що проектується у емергентний простір, то це життя як новий жанр мистецтва антикомедія, адже комедія - це твір про романтику, кохання, щасливий кінець. Етапи життя співвідносяться зі структурою театральної вистави, перформансу, де третій акт відповідає середньому віку. Особиста криза головного персонажа зумовлює визначення його життя як комедії нового жанру. Відтак, емергентний простір містить нову інформацію, що модифікує наше сприйняття комедії, визначає іiї як антикомедію, фіналом якої є нещасливий кінець шлюбу, розлучення, професійна невдача, провал. У цій інтеграційній мережі відбувається компресія зовнішньо-просторових зв'язків (outer-space relations) до внутрішньо-просторових (inner-spacerelations): компресія людського життя до обсягу вистави / фільму певного жанру. Ця операція можлива завдяки відношенням аналогії [11, с. 311].

Розглянемо іншу інтеграційну мережу, що ілюструє невідомий тип персонажа DOCTOR IS FIEND (ЛIКАР - ДЕМОН). Перш за все, бленд актуалізується інформацією, що суперечить нашому 
уявленню про людей медичної професії. "Dr. Young. For we, we, we! - we demolish the human body [2, c. 83]; "I wear my surgical gown, my skintight rubber gloves. I wear an outlaw's mask. My headlight band is connected to a transformer on the floor, half submerged in blood. The cord goes down my back, under my surgical gown, and wiggles around behind me, like tail of monkey, tail of fiend" [2, с. 84-85]. Події, описані в романі, насправді слід інтерпретувати як протилежні. Семантика лексем змінена на зворотну: "забирає життя” означає "рятує”, “знищує людське тіло" насправді означає “зцілює”. Хоча лікар просто виконує свої професійні обов’язки, а події роману розгортаються в протилежному напрямі, М. Аміс використовує таку оповідну тактику для того, щоб надати ключі до минулого персонажа, лікаря Янга. Аналізуючи структуру цієї інтеграційної мережі, можна сказати, що умовою для проведення операції концептуального блендингу $\epsilon$ наявність певних параметрів простору-джерела (агент, особа, яка зазнає впливу агента, зовнішні атрибути, процедура, ціль діяльності). Вхідний простір 1 містить такі значення: лікархірург, пацієнт, зовнішні атрибути професії- халат, маска, гумові рукавиці, ліхтар на пов'язці на голові, шнур від якого звисає з-під халата; мета - зцілити. Вхідний простір 2 містить інформацію: агент - диявол, жертва - об’єкт демонічного ритуалу, атрибути - маска злочинця на обличчі, хвіст диявола, що звисає з-під низу. Мета - знищення жертви. Процес обробки цієї інформації передбачає залучення фонових знань про професію хірурга та образ диявола. Емергентний простір компонується вибірковою інформацією - агент / лікар-хірург, пацієнт, атрибути - маска злочинця, хвіст диявола, мета - знищення пацієнта. Невідповідність значення агента атрибутам та меті створює новизну, прирощення значення в емергентному просторі. Насправді автор роману “Стріла часу” (“Тime’s Arrow”), події якого розгортаються від смерті до народження, поступово розкриває перед читачем справжню особистість головного персонажа лікаря Янга / Оділо Унфердорбена, лікаря-нациста з табору Аушвіц, який замість того, щоб лікувати, знищував.

Наступним аналізованим концептом є складений іменник-неологізм ВОМВ ВАВҮ (ДИТИНАБОМБА). Простір-джерело в цій інтеграційній мережі містить параметри, що роблять таке зівставлення можливим - предмет, характеристики предмета, джерело влади, результат. При заповненні вхідного простору 1 актуалізується схема фонових знань- немовля. Немовля беззахисне і слабке (характеристики), крик (джерело влади) забезпечує потрібний результат. При заповненні вхідного простору 2 - актуалізовано наші фонові знання про бомбу - предмет, характеристики якого передбачають наявність вибухової речовини, джерелом влади є здатність до деструкції, а наслідком - вибух, тотальне знищення. В емергентному просторі отримуємо немовля, яке виступає в ролі вибухонебезпечного пристрою, бомби. Це немовля 3 вбивчою силою плачу, який настільки нестерпний, що знищує все навкруги, заставляє підкорятися: "Is the baby - is das Baby the bomb baby? The baby that has such power over its parents? I don't think so. Our baby (which has a name: Eva) exerts colossal power as a subject. But not the physical power that the bomb baby exerted, over its parents and over everybody else in the black room: some thirty souls" [2, с. 135]. Нестерпний крик немовлят у газових камерах переслідує героя в снах. Він навіть вагається щодо власної дитини, чи не має вона такої самої влади над людьми: “Our German baby is of startling dimensions: bigger, if anything, than the woman herself. Herta is no more than the string on the parcel in which the baby sleeps" [2, c. 147]. "Our baby is a bomb, too: a time bomb" [2, с. 152]. Семантика речень породжує паралелі: Герта $є$ лише контейнером, а дослівно “посилкою, перев'язаною стрічкою”, що містить дитину-бомбу, бомбу сповільненої дії.

Побудова інтеграційної мережі ментальних просторів для ілюстрації когнітивної операції, співвідносної з гіпотетичним судженням “But say Thumberlina had married the mole?” в романі М. Аміса "Ноuse of Meetings", передбачає залучення інформації з роману та фонових знань прецедентного тексту, казки Г. Х. Андерсена про Дюймовочку (“Thumberlina”). Порівнюючи одруження Зої (фатальної жінки, що любить життя і кохання) та Льва (брата оповідача; непривабливого, але доброго романтика-інтелектуала, зруйнованого перебуванням у концтаборі) з одруженням персонажів казки Дюймовочки і Крота, автор змушує нас припустити ситуацію, якої не було, адже за сюжетом Дюймовочка втікає від Крота перед самим весіллям: "But say Thumbelina had married the mole. And let's consider it from the mole's point of view. They 
live together under the soil, in unbreathable damp and darkness. The tiny beauty is a devoted wife. And yet the mole, who can't help being half blind, can't help hating flowers and sunshine, feels the thwartedness of Thumbelina - Thumbelina, who was born from a tulip. It is not in the mole to ask her to go. So he makes his grotto more gravelike, darker, danker, and wills her to leave" [5, c. 129]. Зробивши таке припущення, автор унаочнює невідповідність персонажів один одному i заставляє нас припустити можливу розв'язку такого шлюбу: “And leave she did, on October 29, 1962. <..> Lev was still in their half of the hovel near Kazan" [5, c. 130]. Незважаючи на відданість і старання, Дюймовочка залишається розчарованою і пригніченою, оскільки Кріт не хоче іншого життя, задоволений тим, що має. Зрештою, їх шлюб приречений на невдачу.

Простір-джерело визначає базові параметри (WIFE, HUSBAND, HOUSE) для зівставлення в межах цієї інтеграційної мережі. Вони грунтуються на наявності в наших фонових знаннях схеми ШЛЮБ/MARRIAGE. При цьому вхідний простір 1 містить компоненти, що ілюструють персонажів прецедентного тексту, казки про Дюймовочку, (Дюймовочка, Кріт, місце проживання - нора). Вхідний простір 2 містить персонажів роману М. Аміса (Зоя, Лев, місце проживання - маленька темна пошарпана квартира).

\section{Схема концептуального бленду "But say Thumberlina had married the mole?"}

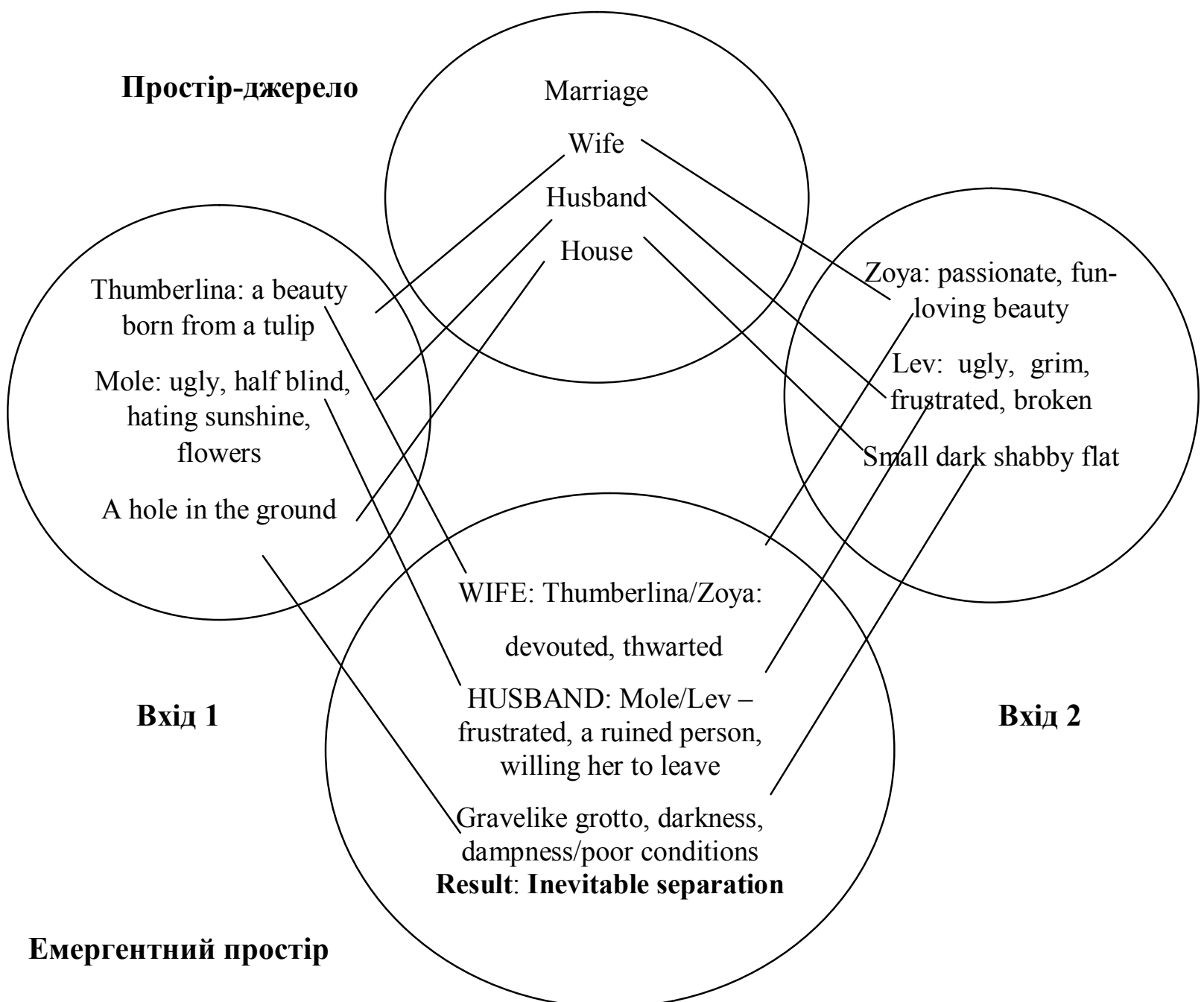

У емергентний простір перенесена така інформація: Дюймовочка/Зоя - віддана дружина, яка згодом згасає, розчаровується. Кріт./Лев зневірений, робить свій грот щораз темнішим і похмурішим і зрештою змушує іiі піти. Як бачимо, не всі ознаки Крота переносяться в емергентний простір, а лише релевантні, такі як фізична потворність та схильність до безрадісного життя під землею, заможність, згадана в казці залишається неактуальною. 
Отже, має місце вибіркове перенесення інформації. Внаслідок обробки даних емергентного простору відбувається зворотна проекція на вхідний простір 1, що заставляє зробити висновок про безперспективність шлюбу персонажів Зої та Льва.

Висновки. У статті запропоновано концептуальний аналіз репрезентативних випадків словотворчості М.Аміса, а саме концептів метафоричного характеру LIFE IS ANTI-COMEDY; DOCTOR IS FIEND; складеного іменника BOMB BABY; гіпотетичного судження "What if Thumberlina had married the mole?", що репрезентовані різноманітними мовленнєвими засобами в тексті. При аналізі підходів теорії концептуальної метафори та теорії концептуального блендингу проілюстровано подібності й розбіжності цих підходів та специфіку застосування їхнього методологічного інструментарію. Встановлено випадки авторської словотворчості, що можуть бути вичерпно проаналізовані в межах теорії концептуальної метафори. Водночас зазначені вище випадки виходять за межі можливостей даної теорії і тому вимагають дещо іншої методики аналізу. Теорія коцептуального блендингу має значний потенціал для пояснення креативного використання стилістичних і наративних індивідуально-авторських прийомів, адже дозволяє пояснити прирощення утвореного значення, що виходить за межі суми значень компонентів. Такий підхід має перспективи для розвитку в подальших дослідженнях семантики експериментальних текстів.

\section{References}

1. Amis, Martin. 1990. London Fields. London and New York: Penguin Books.

2. Amis, Martin. 1991. Time's Arrow. London: Penguin Books.

3. Amis, Martin. 1996. The Information. Flamingo : HarperCollinsPublishers.

4. Amis, Martin. 2003. Yellow Dog. London: Jonathan Cape.

5. Amis, Martin. 2007. House of Meetings. London: Vintage Books.

6. Amis, Martin. 2010. The Pregnant Widow. Inside History. London: Jonathan Cape.

7. Babeliukh, Oksana. 2013. "Sposoby postmodernistskoho tekstotvorennya kriz pryzmu polistylistyky". Odeskyi lingvistychnyi visnyk 1: 5-16.

8. Bekhta, Ivan. 2013. Avtorske eksperymentatorstvo u anhlomovniy prozi XX stolittia. Lviv: PAIS.

9. Bystrov, Yakiv. 2016. "Biohrafichnyi naratyv u linhvokohnityvnomu vymiri (na materiali anhlomovnoi prozy XX - pochatku XXI stolit)". PhD diss., Kyiv.

10. Evans, Virginia. 2006. Cognitive Linguistics: An Introduction. Edinburgh: Edinburgh University Press.

11. Fauconnier, Gilles, and Mark Turner. 2003. The way we think: conceptual blending and the mind's hidden complexities. Basic Books.

12. Izotova, Natalia. 2018. "Khudozhniy naratyv u konteksti ihrovoi stylistyky". Aktualni pytannia humanitarnykh nauk 20: 63-67. doi.org/10.24919/2308-4863.1/20.167364

13. Lakoff, George. 2004. Zhenshchiny, ogon i drugie opasnyie veshchi: chto kategorii yazyka govoriat nam o myshlenii. Moskva: Yazyki slavianskoi kultury.

14. Moskvchova, Oksana. "Emerhentni kohnityvni struktury v poetychnomu teksti u svitli teorii kontseptualnoi intehratsii mentalnykh prostoriv". Problemy humanitarnykh nauk. Ser.: Filolohiia 42: 107-118. doi.org/10.24919/2522-4557.2018.42.152342

15. Semino, Elena. 2006. "Blending and character's mental functioning in V. Woolf's 'Lapin and Lapinova"'. Language and Literature 15(1): 55-72. doi: 10.1177/0963947006060555

16. Tsur, Reuven. 2008. Toward a Theory of Cognitive Poetics. Succex Academic Press.

17. Vorobyova, Olha. 2009. "Evrystyka modernistskoho metodu u kohnityvno-poetolohichnomu vysvitlenni". Visnyk KNLU. Seriia Filolohia 1: 31-43.

18. Vorobyova, Olha. 2013. "Khudozhniy tekst: u poshukakh metametodu interpretatsii". Anhlistyka ta amerykanistyka 10: 7-11.

Гураль Оксана. Креативная экспрессивность англоязычного постмодернистского романа в свете теории концептуального блендинга. Статья посвящена раскрытию специфики применения теории концептуального блендинга и теории концептуальной метафоры для анализа глубинной семантики постмодернистского англоязычного наратива. Когнитивный подход к анализу текста является необычайно актуален поскольку раскрывает значительно большие возможности для интерпретации текстовых тактик и индивидуальноавторских приемов. В статье предлагается сопоставление теории концептуальной метафоры и концептуального блендинга за несколькими параметрами - способом применения, единицами анализа, возможностями, появляющимися в процессе применения этих теорий к анализу текста, а также их познавательным потенциалом. В то время, как первая из них концентрирует свои усилия на поисках обобщений в широком спектре метафорических выражений, вторая - фокусируется на природе и особенностях специфических примеров, способствуя наработке общих принципов такого построения. Текст англоязычного постмодернистского наратива в целом структурирован конвенциональными концептуальными метафорами, которые в свою очередь подвергаются разнообразным 
трансформациям в процессе реализации авторского творческого замысла, а именно расширения, компресии, смещения, использования раньше неиспользованной части концептуальной метафоры. В статье предлагается анализ новаторских концептов при помощи теории концептуальной интеграции. В частности, предложен анализ дополнительной семантики в емергентных пространствах блендов LIFE IS ANTI-COMEDY, DOCTOR IS FIEND, pacкрыты особенности текстового воплощения концептуальной конфигурации бленда гипотетического суждения-алюзии: “But say Thumberlina had married the mole?”, прирост значения на примере сложного имени существительного вомВ ВАВY. Таким образом обоснованы дополнительные возможности, открывающиеся в рамках теории концептуального блендинга для моделирования глубинной семантики индивидуально-авторских выражений в сопоставлении с теорией концептуальной метафоры.

Ключевые слова: концептуальный бленд, ментальное пространство, концепт, концептуальная метафора, гипотетическое суждение.

Hural Oksana. Creative Expressiveness of Postmodernist English Novel within Conceptual Blending Theory. The article deals with the peculiarities of application of conceptual blending theory as well as conceptual metaphor theory to the analysis of the deep semantics of postmodernist English novel. Nowadays cognitive approach seems to be a prolific field of research into the intricacies of experimental texts. The perspectives of conceptual metaphor theory and conceptual blending theory are contrasted in terms of the ways of application, units of analysis, capabilities involved in the process of textual analysis and their heuristic potential. Whilst the former focuses on the search of generalizations across a wide range of metaphorical expressions, the latter - concentrates its efforts on the nature and specificity of individual examples, facilitating the classification of the general principles of such construction. Although postmodernist English narrative is predominantly structured by conventional conceptual metaphors, they enter a number of transformation processes like extension, compression, substitution, the usage of previously unused part of a conceptual metaphor in the course of realization of author's intention. The article discusses the benefits of conceptual blending theory for the analysis of some idiosyncratic stylistic devices and narrative techniques. The meaning of the emergent mental spaces in the conceptual blends LIFE IS ANTICOMEDY, DOCTOR IS FIEND are subject to analysis, alongside with the conceptual blends created by a counterfactual " $B u t$ say Thumberlina had married the mole?" and a compound noun BOMB BABY. The counterfactual being also an allusion to a wellknown fairy tale, the process of creation of new emergent space is being modelled and the possibilities of backward projection are being discussed. Therefore, it is possible to presume that conceptual blending theory has a potential to offer new insights into the nature of innovative complex textual concepts found in postmodernist English narrative and thus complement the capabilities of conceptual metaphor theory.

Key words: conceptual blending, mental space, concept, conceptual metaphor, counterfactual.

DOI: https://doi.org/10.32782/2410-0927-2020-12-13

УДК 811.111 '373.43-11

Майя Жулінська

\section{ВЕРБАЛІЗАЦЯ КОНЦЕПТУ "НOUSING" АНГЛЙИСЬИМИ НЕОЛОГІЗМАМИ}

Стаття присвячена аналізу неологізмів концепту “HOUSING”, сформованих внаслідок змін у суспільному житті, і причин їх виникнення в наші дні. Об'єктом вивчення даного дослідження стали лексичні інновації, що 3'явилися в англійській мові протягом останнього року.

Подано короткий огляд теоретичних підходів до проблеми вивчення неологізмів. Описано роль неологічних процесів у сучасній англійській мові. Окреслено причини, які зумовлюють потребу в необхідності дослідження нової лексики 3 позицій когнітивної лінгвістики. Визначено поняття концепту як базового в когнітивній лінгвістиці. Звернуто увагу на розуміння концепту в сучасній науці.

У статті наголошено на універсальності концепту “HOUSING", наведено варіанти перекладу лексеми "housing" на українську мову згідно з аналізом відомих словників. В результаті розподілу лексичних інновацій відповідно до змістових ознак цього концепту виокремлено п'ять основних i додаткових концептуальних характеристик: будівля для проживання чи інших иілей; параметри і розмір; прибудинкова територія; будівельний матеріал та житлові відносини. Подано приклади найцікавіших нових слів та їх першоджерела; тлумачення досліджуваних неологізмів, оскільки вони ще не мають перекладу на українську мову; приклади їх уживання в сучасних англомовних виданнях.

Проаналізовано зміни конструкторської і дизайнерської думки, які трансформуються в нові стилі в архітектурі, вплив прагнень сучасної людини на облаштування власної оселі і відповідно зміни в лексичному складі мови у зв' язку 3 необхідністю нової номінації. Проведено статистичний аналіз неологізмів за способом утворення, в ході якого словоскладання і телескопія виділені як найбільш продуктивні способи утворення неологізмів концепту “HOUSING”. Встановлено основні причини появи нових слів: нові об’єкти номінації, економія мовних засобів, гра слів.

(с) Жулінська М., 2020 